\title{
PENGARUH VARIASI JUMLAH FASTENER TERHADAP KEKUATAN STRUKTUR REPAIR LONGITUDINAL FLOOR BEAM PESAWAT B 737-300
}

\author{
Djarot Wahju Santoso \\ Teknik Penerbangan \\ Sekolah Tinggi Teknologi Adisutjipto \\ Jalan Janti Blok-R Lanud Adisutjipto, Yogyakarta \\ djarot_wahyu84@yahoo.com
}

\begin{abstract}
Longitudinal floor beam structure is a rod that serves to support the weight of the passenger seat, the passenger load and luggage on airplanes. Bending load received by the structure continuously during flight operations cause damage (cracks). The presence of cracks in the structure of the repair needs to be done to ensure the safety of the aircraft during operation. Structure Repair Manual (SRM) is a guide issued by the mamufacturer of the aircraft maintenance company to do the repair. In SRM was not stated clearly that the repair is safe. To determine the level of safety of longitudinal floor beam structure repair Boeing 737-300 fractured analysis is needed also to determine the effect of the number of fasteners to the strength of the modified structure.

Modeling and analysis of longitudinal structural floor beam using CATIA V5R16 software. Imposition of the structure using a bending load due to the load compartment main cabin. Four models are made in accordance with the repair of such structures to handle SRM model fractured. Modifications done by reducing fastener types BACB3OFN6 6 to 5 and 4 fastener on the upper area of the beam. Static analysis performed on models with CATIA V5R16 to determine the safety of the structure is based os margin of safety.

The results of analysis that the longitudinal floor beam structural repair the fractured secure against bending loads. The use of a modified structure repair by reducing the number of fastener would increase the critical stress that occurs, but the structure is still safe to load.
\end{abstract}

Keywords: fastener, repair, longitudinal floor beam

Abstrak

Struktur longitudinal floor beam merupakan batang yang berfungsi untuk menahan beban dari kursi penumpang, beban dan bagasi penumpang pada pesawat terbang. Beban bending yang diterima oleh struktur tersebut secara terus menerus selama proses operasi penerbangan menyebabkan terjadinya kerusakan (retak). Adanya retak pada struktur tersebut perlu dilakukan repair untuk menjamin keselamatan pesawat selama dioperasikan. Structure Repair Manual (SRM) merupakan panduan yang dikeluarkan oleh manufaktur kepada perusahaan perawatan pesawat untuk melakukan repair. Dalam SRM tidak dinyatakan secara jelas bahwa repair tersebut aman. Untuk mengetahui tingkat keamanan struktur repair longitudinal floor beam pesawat Boeing 737-300 yang mengalami retak maka perlu dilakukan analisis juga untuk mengetahui pengaruh jumlah fastener terhadap kekuatan struktur modifikasi tersebut. 
Pemodelan dan analisis struktur longitudinal floor beam menggunakan software CATIA V5R16. Pembebanan struktur menggunakan beban bending akibat beban compartment kabin utama. Empat model dibuat pada repair struktur tersebut sesuai dengan SRM untuk menangani model yang mengalami retak. Modifikasi dilakukan dengan mengurangi 6 fastener tipe BACB30FN6 menjadi 5 dan 4 fastener pada area upper beam. Analisis statik dilakukan pada model dengan CATIA V5R16 untuk menentukan keamanan struktur tersebut berdasarkan Margin of safety.

Dari hasil analisis diperoleh bahwa struktur repair longitudinal floor beam yang mengalami retak aman terhadap beban bending. Penggunaan struktur modifikasi repair dengan cara mengurangi jumlah fastener akan meningkatkan tegangan kritis yang terjadi, namun struktur tersebut masih aman terhadap pembebanan.

\section{Kata kunci:fastener, repair, longitudinal floor beam.}

\section{Pendahuluan}

Fuselage merupakan bagian dari pesawat selain sebagai tempat penumpang dan barang juga sebagai bagian untuk menempatkan sayap, vertical dan horizontal tail, dan powerplant. Pengaruh beban pada rancangan fuselage dapat dihasilkan dari flight maneuver, landing atau kondisi ground handling. Pembebanan pada fuselage merupakan masalah utama dalam menentukan pembagian berat oleh beban penumpang dan barang, beban pada ekor dan beban pada nose landing gear. Pendistribusian berat penting karena sebagian besar beban fuselage bersumber dari massa inersia yang ada ketika terjadi percepatan, baik translasi dan rotasi. Salah satu pembebanan yang terjadi pada fuselage adalah tekanan kabin (cabin pressure).

Struktur pesawat harus dibuat dengan kuat agar mampu menahan gaya yang diterima dari beban di atas. Gaya yang bekerja pada struktur dapat menyebabkan terjadinya perubahan bentuk atau kegagalan struktur. Kegagalan struktur merupakan suatu kondisi di mana struktur tidak dapat digunakan dalam waktu yang sangat lama. Kegagalan struktur sebenarnya masih dapat diterima selama masih dalam batas pakai dan unjuk kerja yang layak. Melihat pentingnya fungsi fuselage bagi sebuah pesawat, maka struktur fuselage harus dirancang dan dirawat untuk memenuhi fungsinya dengan baik untuk menjamin keselamatan dan keamanan pesawat itu sendiri.

Fokus utama pada perancangan struktur pesawat terbang dalam perkembangannya berada pada kekuatan, namun saat ini perancangan struktur pesawat juga memperhatikan kriteria kegagalan aman (fail-safe), kelelahan (fatigue), korosi, perawatan dan pemeriksaan (maintenance \& inspection), serta kemampuan produksi. Struktur pada rancangan pesawat terbang memiliki fungsi memberikan bentuk luar (surface) yaitu untuk memenuhi persyaratan aerodinamis dan fungsinya. Struktur pesawat harus mampu menahan semua pembebanan seperti gaya dorong mesin dan gaya dari roda pendarat. Serta mampu menyangga semua pembebanan sebagai akibat berat statik struktur. Untuk itu pesawat harus memenuhi beberapa persyaratan dasar yaitu ringan, cukup kuat, kokoh.

Struktur pesawat terbang modern dirancang menggunakan jenis semi monocoque, di mana suatu pembebanan pada fuselage ditahan oleh shell yang diperkuat struktur frame, stringer, longeron, skin. Sedangkan beban penumpang, kursi penumpang, serta bagasi penumpang ditopang oleh longitudinal floor beam.

Dalam perawatan pesawat pada struktur yang mengalami kerusakan harus dilakukan repair (perbaikan) mengikuti panduan yaitu SRM (Structure Repair Manual). Menurut SRM sudah ditentukan prosedur dan cara memperbaiki suatu struktur yang mengalami kerusakan. Dalam ketentuan SRM tidak dijelaskan kenapa struktur yang mengalami kerusakan harus 
direpair seperti petunjuk yang telah ditetapkan. Sebagai contoh dalam repair skin, jarak spasi antara fastener mengikuti aturan yang tertentu, begitu juga jarak minimum fastener dengan ujung tepi skin. Mengenai aturan yang tercantum dalam dokumen tersebut tidak dijelaskan bagaimana cara menganalisisnya, tetapi bila repair dilaksanakan sesuai panduan tersebut keamanan struktur akan terjamin. Berdasarkan hal tersebut peneliti ingin mengetahui mengapa ketentuan ini bisa diterapkan serta bagaimana variasi jumlah fastener mempengaruhi kekuatan struktur, dalam hal ini diambil studi kasus struktur repair longitudinal floor beam pesawat Boeing 737-300 yang mengalami retak sesuai ketentuan SRM.

Adapun tujuan yang ingin dicapai dalam penelitian ini adalah :

1. Memodelkan struktur longitudinal floor beam pesawat Boeing 737-300 dan menganalisis kekuatan struktur repair yang mengalami retak berdasarkan SRM.

2. Menentukan pengaruh variasi jumlah fastener terhadap kekuatan struktur floor beam $\mathrm{B} 737-300$ setelah mengalami modifikasi.

\section{Struktur Longitudinal Floor Beam Pesawat B 737-300}

Struktur longitudinal floor beam merupakan batang yang berfungsi untuk menahan beban dari kursi penumpang, beban dan bagasi penumpang pada pesawat terbang. Struktur ini terdiri dari gabungan (assembly) beberapa bagian (part) seperti seat track type II, seat track type III, transverse beam, upper beam, strap, shim, angle $90^{\circ}$, angle $45^{\circ}$, web dan lower beam.

Pada umumnya struktur longitudinal floor beam ditempatkan di kabin utama pesawat, tepatnya di bawah kursi penumpang. Karena letaknya di bawah kursi penumpang maka struktur longitudinal floor beam tidak terkait secara langsung dengan konstruksi skin pesawat yang ditopang oleh beberapa komponen seperti frame, bulkhead, stringer dan longeron. Sehingga beban yang diterima struktur tersebut hanya berupa beban bending yang berasal dari kursi penumpang, beban dan bagasi penumpang.

Akibat beban bending yang diterima oleh longitudinal floor beam secara terus menerus selama proses operasi penerbangan dari fase take-off sampai fase landing dapat menyebabkan terjadinya kerusakan (damage) pada struktur tersebut. Dalam kasus ini, kerusakan terjadi pada Section 46 Body Station 727B, LBL 45.50, berupa retak sepanjang 0,31 in pada bagian chord upper beam sebelah kiri seperti yang terlihat pada Gambar 1 .

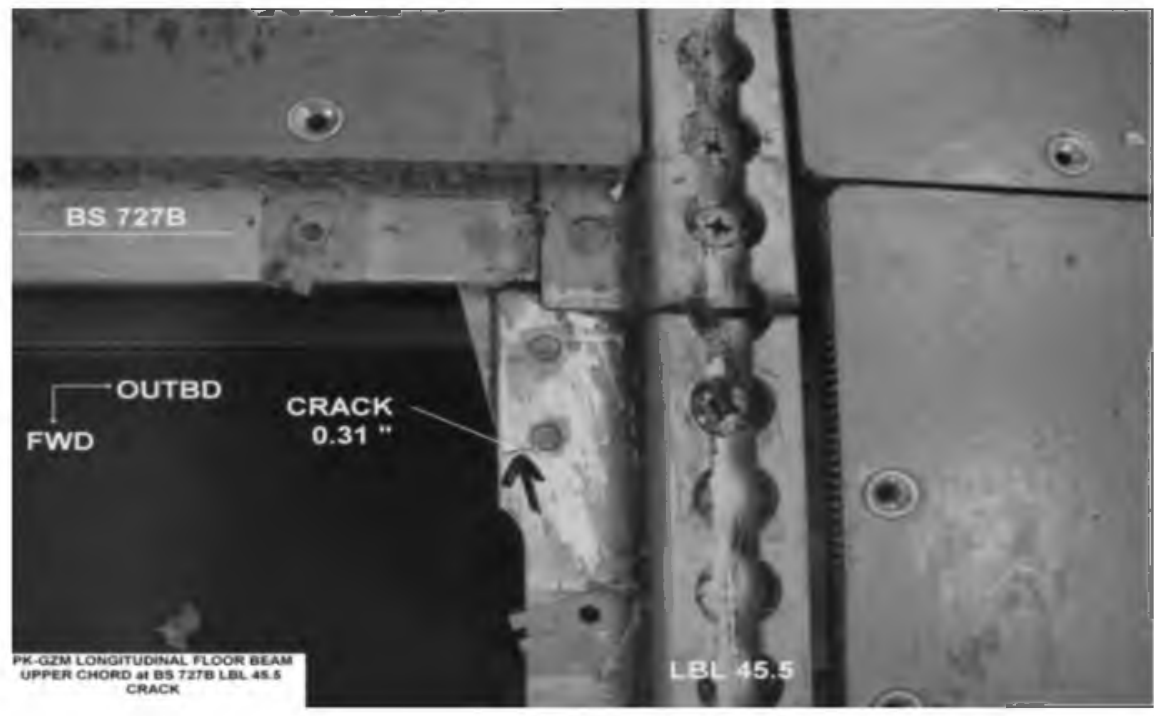

Gambar 1. Retak pada struktur Longitudinal Floor Beam di bagian Section 46,

(Sumber: PT. Garuda Maintenance Facility, Engineering Services, Unit TE) 
Untuk memperbaiki struktur tersebut agar pesawat aman dioperasikan dilakukan repair seperti yang tertuang dalam SRM (Structure Repair Manual). SRM ini berisi panduan untuk melaksanakan repair damage yang terdapat pada struktur pesawat tersebut. Untuk repair struktur longitudinal floor beam terdapat pada SRM Chapter 53-60-51, 51-00-00, 5120-01, 51-20-06 dan 51-30-01. Lokasi profil longitudinal floor beam Body Station pesawat Boeing 737-300 terlihat pada Gambar 2.

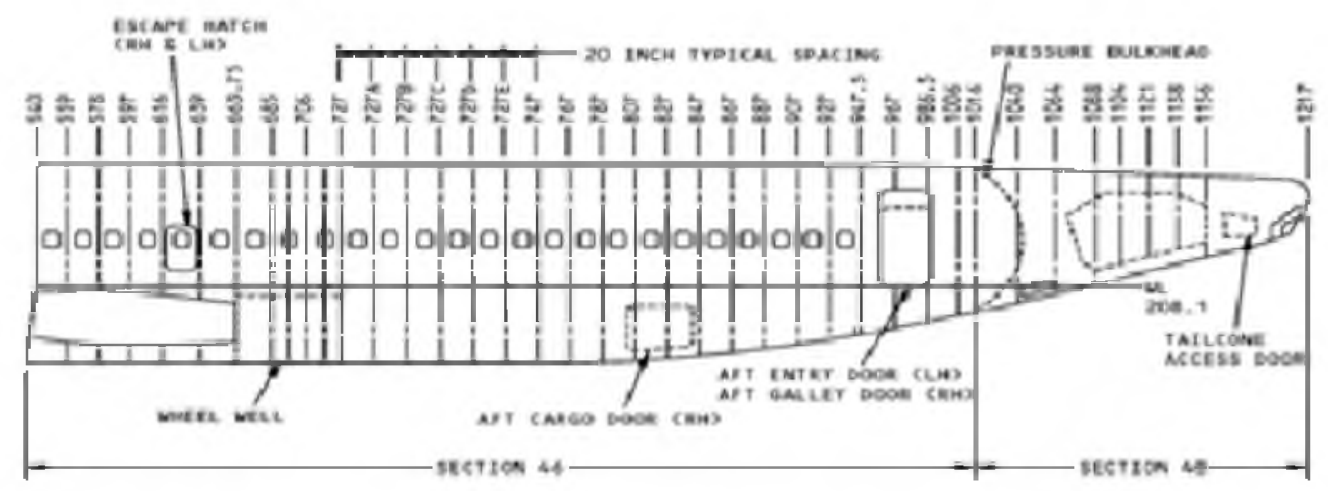

Gambar 2 Body Station Pesawat Boeing 737-300 Section 46 (Sumber: Boeing 737-300, Structure Repair Manual, Chapter 53-00-00)

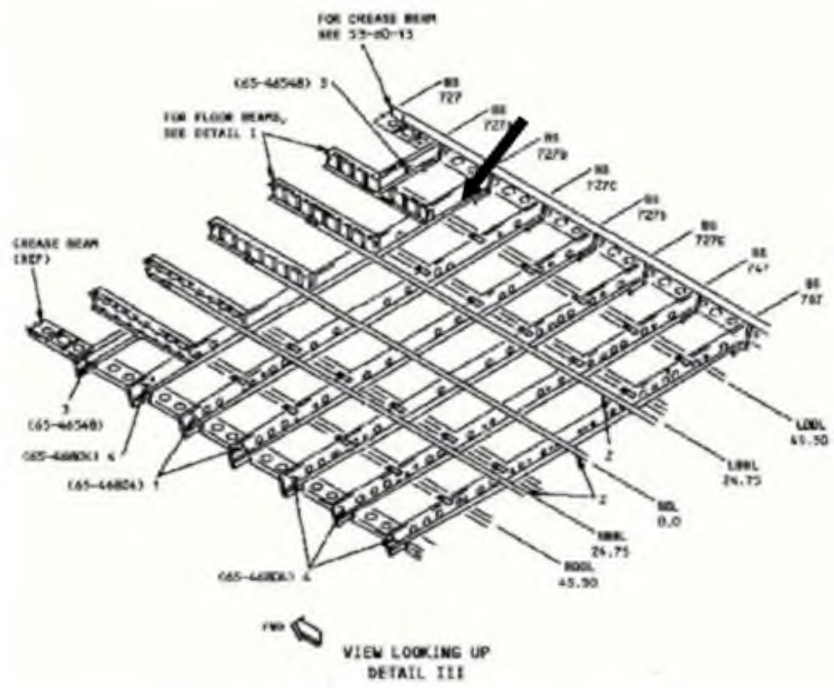

Gambar 3 . Posisi Longitudinal Floor Beam Section 46, Body Station 727B, LBL 45.50

(Sumber: Boeing 737-300, Structure Repair Manual, Chapter 53-60-51)

Secara garis besar dalam SRM disebutkan sebelum melaksanakan repair longitudinal floor beam bagian strap 65-48804-86/87 pada posisi depan upper chord longitudinal floor beam di Body Station 727B dihilangkan. Kemudian potong (trim out) daerah upper chord yang terkena retak dengan mempertahankan garis tepi yang berdekatan dengan lokasi fastener pada jarak minimum 2D (diameter). Langkah selanjutnya membuat filler untuk menutupi cut out serta membuat strap 1 dan 2 untuk menggantikan strap 65-46804-86 dan juga strap 3 dan 4 untuk menggantikan strap 65-46804-87 dengan mempertahankan jarak 2D dari tepi strap dan 4D sampai 6D untuk jarak spasi pada seluruh fastener. 
Besarnya beban (load transfer) yang diterima oleh masing-masing rivet fasterner tergantung dari jumlah rivet, variasi penempatan rivet, ketebalan lapisan layer (plat) yang menahan rivet tersebut (Iryani, 2009). Sedangkan tegangan geser yang terjadi pada rivet tergantung pada formasi pemasangan susunan rivet lap joint (Suyogkumar, 2013).

\section{Pemodelan Struktur Longitudinal Floor Beam}

Pada penelitian ini data dimensi struktur longitudinal floor beam pesawat Boeing 737300 diperoleh dari PT Garuda Maintenance Facility (GMF), Engineering Services, Jakarta. Pemodelan dan analisis struktur menggunakan software CATIA V.5 R.16. Struktur yang dianalisis dimodelkan menjadi 4 macam sebagai berikut :

- Model 1: struktur longitudinal floor beam retak (dibuat sepanjang 0.31 in pada upper beam, 2 fastener pada strap).

- Model 2: struktur longitudinal floor beam repair sesuai SRM (6 fastener pada upper beam).

- Model 3: struktur longitudinal floor beam repair modifikasi 1 (5 fastener pada upper beam). upper beam).

- Model 4: struktur longitudinal floor beam repair modifikasi 2 (4 fastener pada

Berikut adalah hasil pemodelan part yang menyusun sruktur longitudinal floor beam (lihat Gambar 4 sampai dengan Gambar 8).
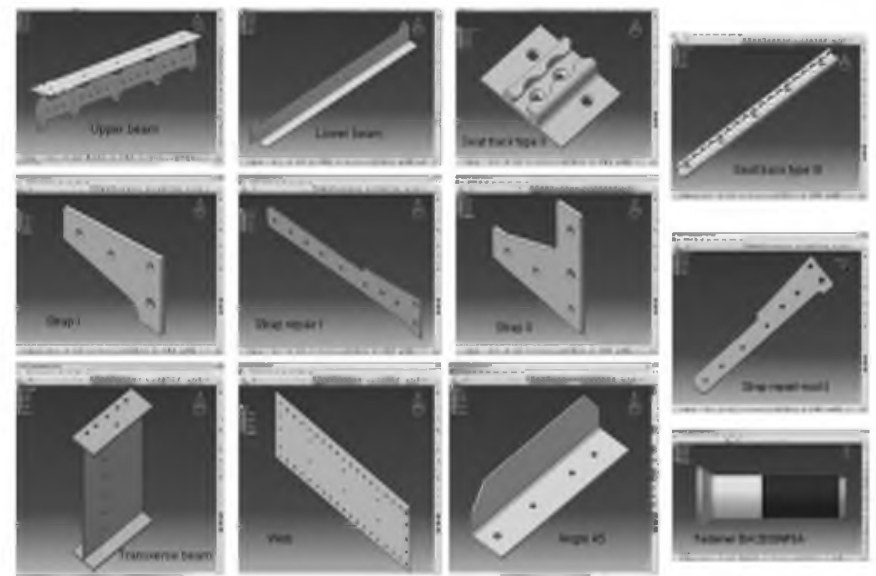

Gambar 4. Part yang menyusun struktur longitudinal floor beam

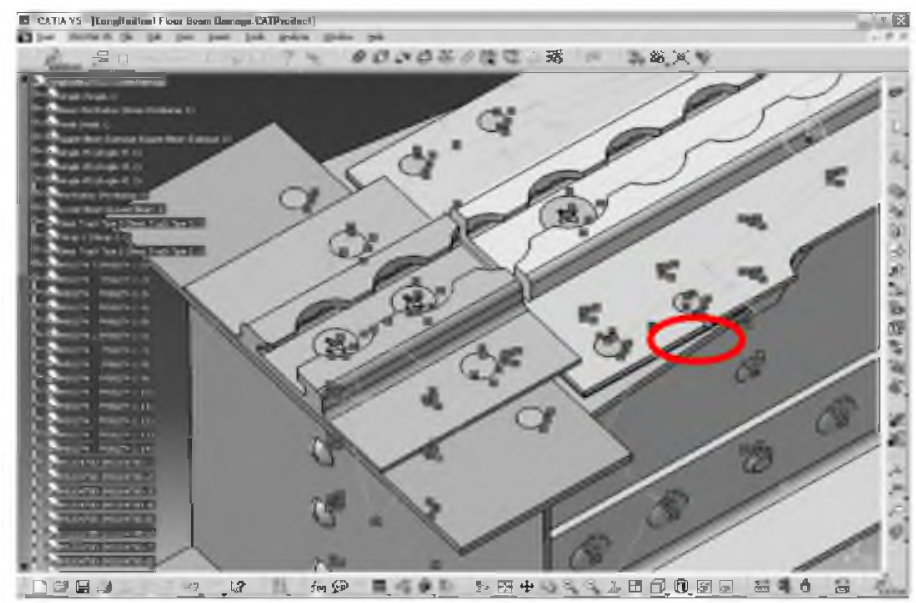

Gambar 5. Model 1 Struktur longitudinal floor beam yang mengalami retak 


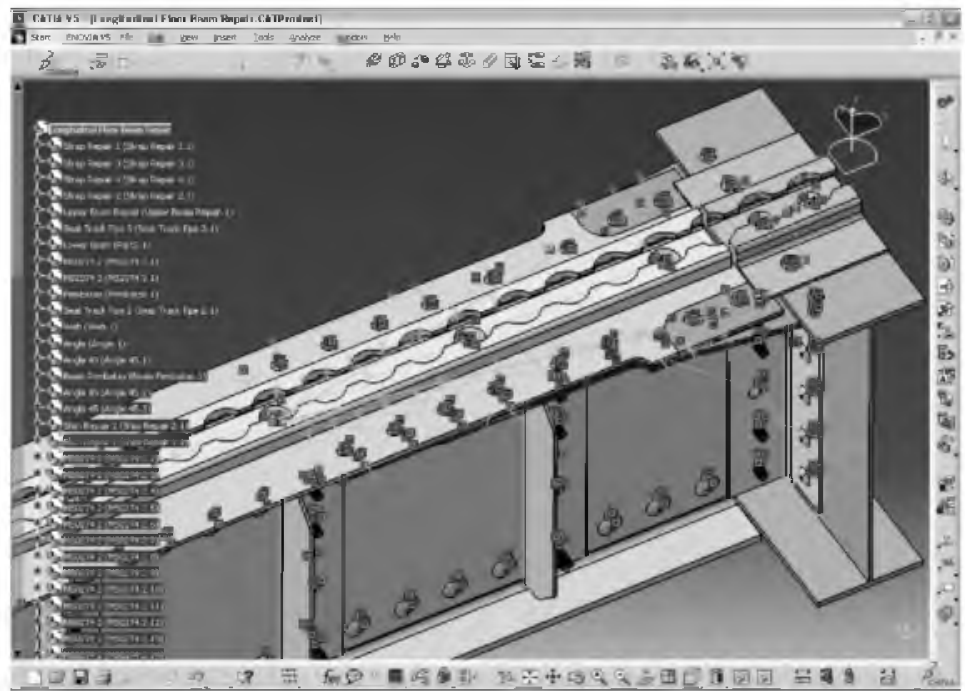

Gambar 6. Model 2 Struktur longitudinal floor beam repair sesuai SRM

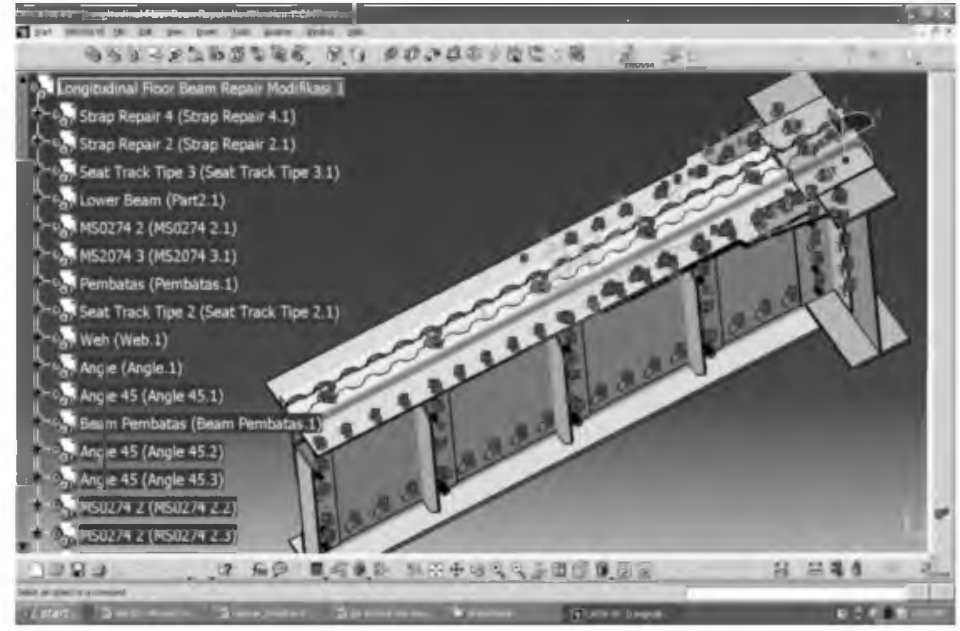

Gambar 7. Model 3 Struktur longitudinal floor beam repair modifikasi 1

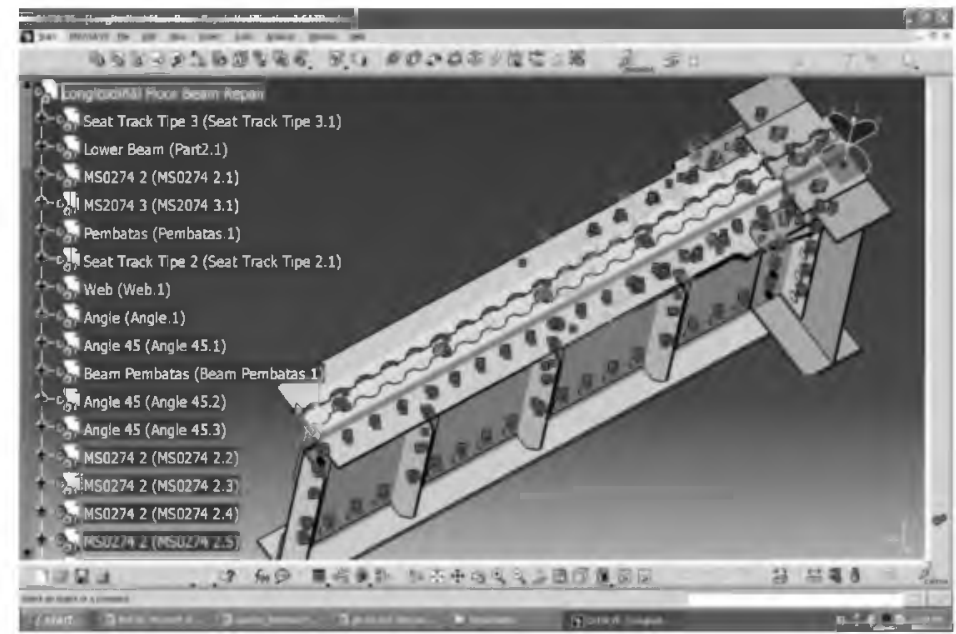

Gambar 8. Model 4 Struktur longitudinal floor beam repair modifikasi 2 


\section{Kondisi Pembebanan}

Pembebanan yang digunakan pada ke empat model adalah sama yaitu beban bending yang berasal dari beban compartment main cabin Boeing 737-300 sesuai dengan standar operasi penerbangan sebesar $42,8 \mathrm{lb} / \mathrm{in}$. Beban tersebut ditahan oleh 5 buah struktur longitudinal floor beam dengan distribusi yang merata pada upper beam, sehingga besarnya adalah sebagai berikut (lihat Persamaan 1):

$$
\begin{aligned}
\mathrm{F} & =\frac{\text { Ukuran Model Floor Beam } \times \text { Weight Main Gabin }}{\sum \text { gtruhtur FLoor Beam }} \\
& =\frac{20 \mathrm{in} \times 42,8 \mathrm{lb} / \mathrm{in}}{5} \\
& =171,2 \mathrm{lb}=761,535 \mathrm{~N}
\end{aligned}
$$

\section{Hasil dan Pembahasan}

\subsection{Analisis Struktur Longitudinal Floor Beam Retak}

Pada model 1, beban bending sebesar $42,8 \mathrm{lb}$ /in diterapkan pada seluruh permukaan atas floor beam. Jenis restraint yang digunakan adalah Clamp surface. Clamp diletakkan pada kedua ujung tepi struktur floor beam yaitu transverse beam dan angle. Nilai tegangan Von mises maksimum adalah $2,4 \times 10^{6} \mathrm{~N} / \mathrm{m}^{2}$ terletak pada ujung fastener MS20470D 3, sedangkan tegangan yield materialnya sebesar 2,206 x 10 $\mathrm{N} / \mathrm{m}^{2}$ (lihat Gambar 9).

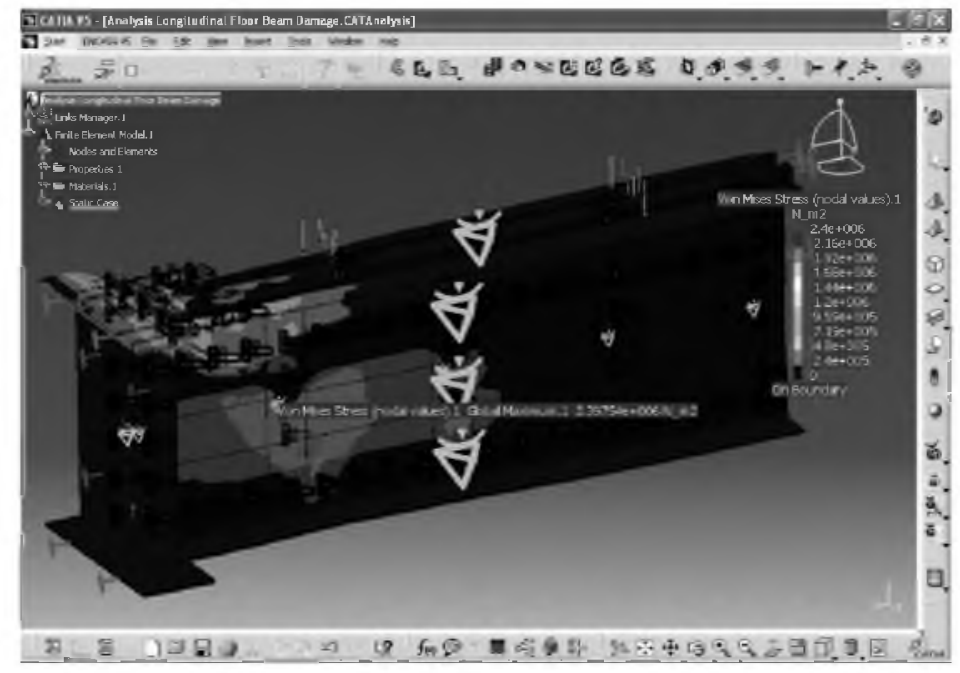

Gambar 9. Nilai tegangan Von Mises maksimum model 1

Pada kasus ini beban bending yang diterima tidak bisa ditahan dengan baik oleh upper beam karena adanya retak (konsentrasi tegangan) sehingga beban akan diteruskan ke part lain yang terletak di bawahnya seperti web dan fastener MS20470D 3. Untuk menentukan kekuatan struktur digunakan nilai Margine of Safety (MS) (lihat Persamaan 2).

$$
\begin{aligned}
& \text { Margin of Safety }=\frac{\sigma_{\text {aldawabie }}}{\sigma_{\text {applied }}}-1 \geq 0 \text { struktur dinyatakan aman } \\
& M S=\frac{2,206 e+008}{2,4 e+006}-1=90,92
\end{aligned}
$$



pembebanan.

Karena nilai MS fastener lebih besar dari nol struktur tersebut aman terhadap

\subsection{Analisis Struktur Longitudinal Floor Beam Repair SRM}

Pada model 2, jumlah fastener BACB30FN6A pada area strap repair adalah 6 buah. Menurut ketentuan SRM jarak antar fastener adalah 4D sampai 6D, pada pemodelan ini digunakan jarak 5D (Diameter). Sedangkan jarak antara fastener dengan ujung tepi strap adalah 2D. Diameter fastener BACB30FN6A adalah 0,1895 in. Nilai tegangan Von Mises maksimum $1,59 \times 10^{6} \mathrm{~N} / \mathrm{m}^{2}$, terletak pada ujung shim repair 2 (lihat Gambar 10). Hal ini terjadi karena part shim repair 2 memiliki ketebalan 0,032 in, lebih tipis dibandingkan part lain yang menahan beban bending secara langsung pada permukaan atas part tersebut (upper beam, filer, shim, strap, web, angle).

$$
M S=\frac{4,275 e+008}{1,59 e+006}-1=267,87
$$

Berdasarkan nilai $M S$-nya struktur tersebut aman terhadap pembebanan bending.

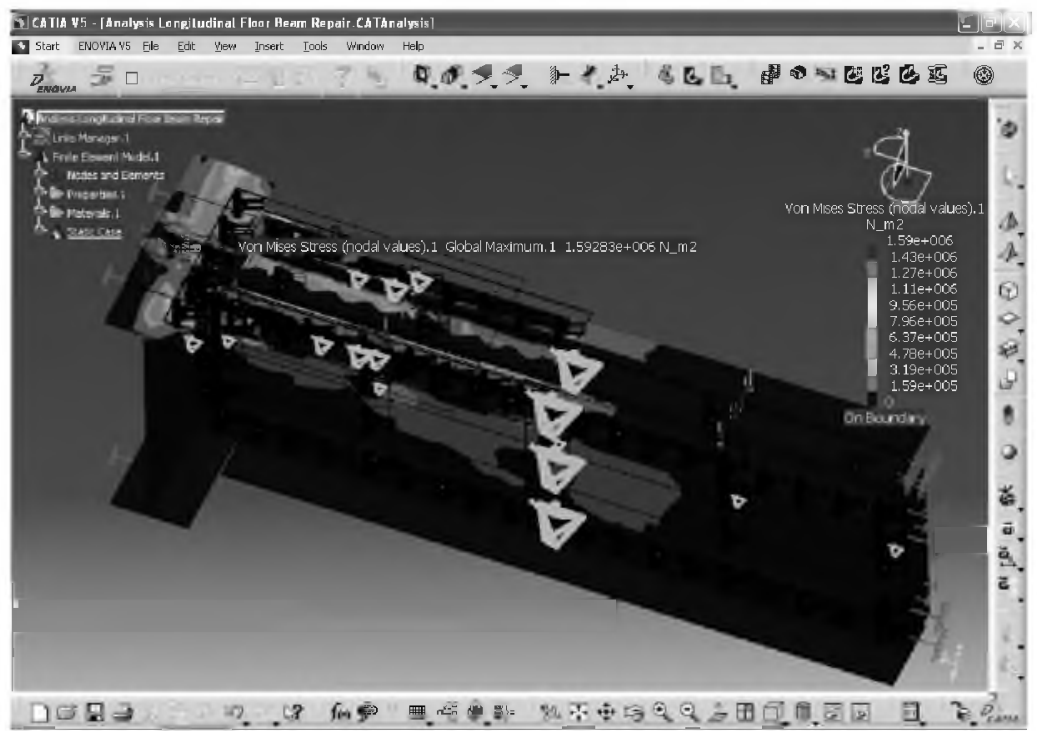

Gambar 10. Nilai tegangan Von Mises maksimum model 2

\subsection{Analisis Struktur Longitudinal Floor Beam Repair Modifikasi 1}

Pada model 3 jumlah fastener yang digunakan adalah 5 buah pada area strap repair. Nilai tegangan Von Mises maksimum $1,66 \times 10^{6} \mathrm{~N} / \mathrm{m}^{2}$ terjadi pada shim repair 2 modifikasi 1 (lihat Gambar 11). Letak tegangan ini terjadi karena part shim repair 2 modifikasi 1 mempunyai ketebalan 0,032 in, lebih tipis bila dibandingkan part lain yang menerima beban bending secara langsung pada permukaan atas part tersebut.

Nilai $M S$ pada shim repair 2 adalah:

$$
M S=\frac{4,275 e+008}{1,66 e+006}-1=256,53
$$

Bila dibandingkan dengan struktur repair SRM (model 2), struktur model 3 nilai tegangan maksimumnya lebih besar dibandingkan model 2 . Hal ini karena jumlah fastener yang digunakan pada struktur model 3 lebih sedikit dibandingkan model 2, sehingga fastener yang menahan beban bending lebih sedikit dibanding struktur model 2 sebagai akibatnya tegangan yang terjadi menjadi lebih besar. 


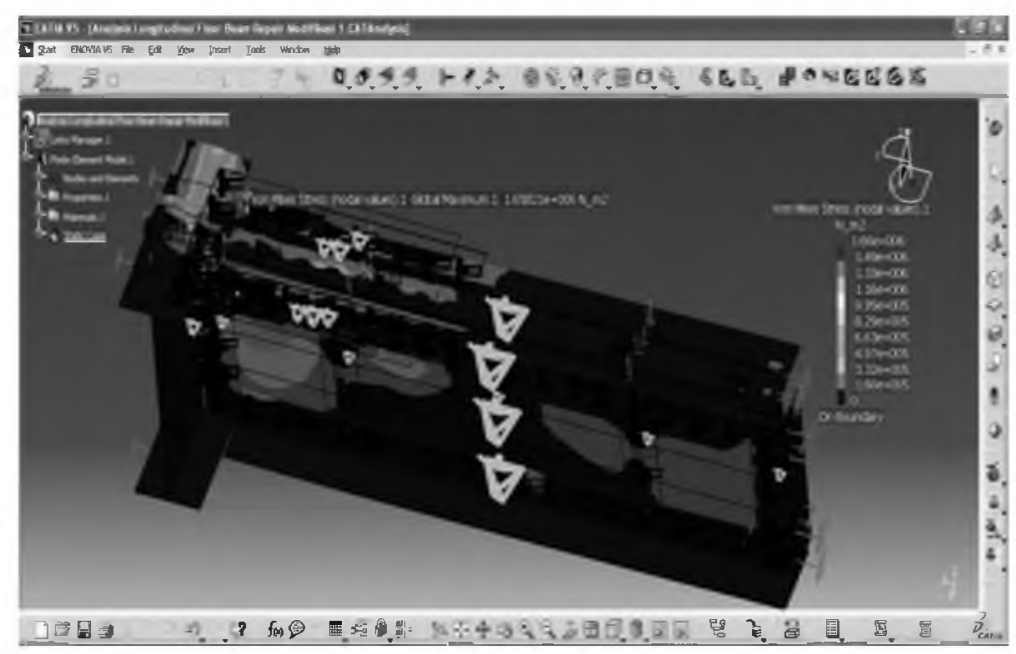

Gambar 11. Nilai tegangan Von Mises maksimum model 3

\subsection{Analisis Struktur Longitudinal Floor Beam Repair Modifikasi 2}

Pada struktur model 4 menggunakan 4 buah fastener pada area strap repair. Nilai tegangan Von Mises maksimum $1,96 \times 10^{6} \mathrm{~N} / \mathrm{m}^{2}$ terletak pada shim repair 1 modifikasi 2 (lihat Gambar 12). Hal ini disebabkan karena part shim repair ini memiliki ketebalan 0,032 in, dimensi ini lebih tipis dibandingkan part lain yang menerima beban bending secara langsung pada permukaan atas part tersebut, begitu juga material properties-nya memiliki yield strength yang lebih rendah bila dibandingkan dengan sruktur lain yang menahan beban tersebut.

Nilai MS shim repair 1 modifikasi 2 adalah :

$$
M S=\frac{4,275 e+008}{1,96 e+006}-1=217,11
$$

Bila dibandingkan dengan model 3, tegangan maksimumnya lebih besar, hal ini karena jumlah fastener yang digunakan model 4 lebih sedikit sehingga fastener yang menahan beban juga lebih sedikit.

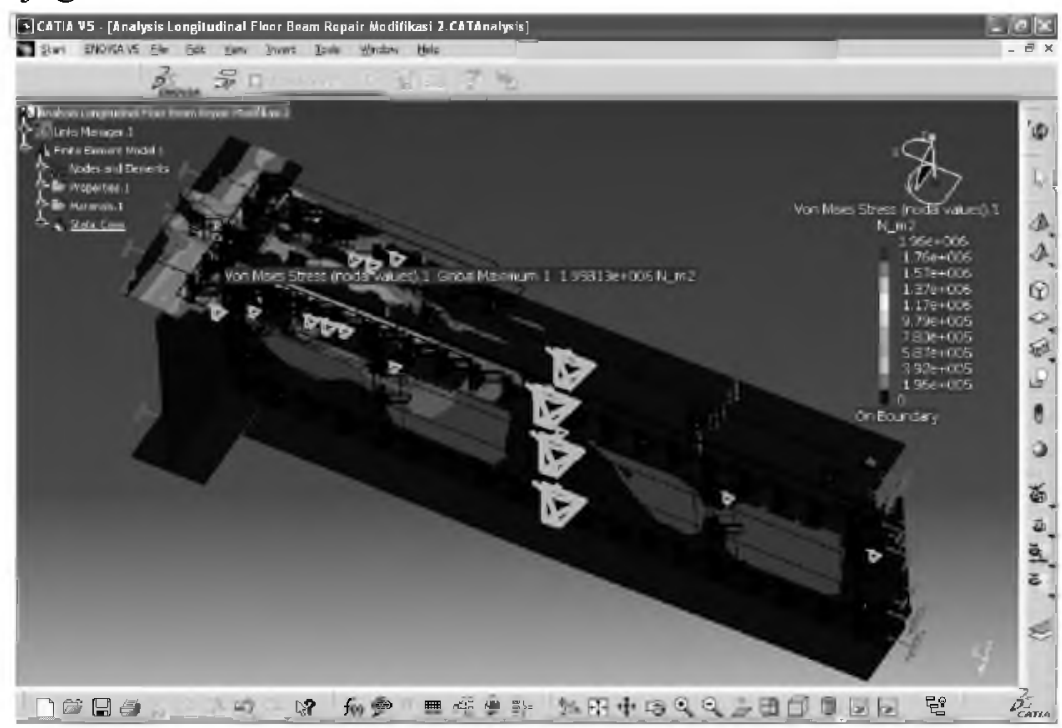

Gambar 12. Nilai tegangan Von Mises maksimum model 4 
Pada model 1, meskipun model sudah diberikan retak namun hasil perhitungan analisis menunjukkan $M S$ lebih besar dari nol, sehingga struktur ini sebenarnya aman terhadap pembebanan. Bila dibandingkan dengan model 2 , tegangan maksimum model 1 lebih besar dari model 2, hal ini menunjukkan pemodelan yang dibuat sudah benar, karena struktur yang telah di repair harus lebih kuat dibandingkan struktur retak sehingga tegangan maksimumnya lebih rendah dibandingkan model retak.

Tabel 1. Nilai Tegangan Von Mises maksimum dan MS pada upper beam pemodelan

\begin{tabular}{|c|l|c|c|}
\hline Model & Assembly Product Floor Beam & $\begin{array}{c}\text { Tegangan } \\
\text { Maksimum }\left(\mathrm{N} / \mathrm{m}^{2}\right)\end{array}$ & $\begin{array}{c}\text { Margine of } \\
\text { Safety }\end{array}$ \\
\hline Model 1 & Floor Beam Retak & $1,39 \times 10^{6}$ & 346,194 \\
\hline Mode1 2 & Floor Beam Repair SRM & $1,16 \times 10^{6}$ & 415,034 \\
\hline Mode1 3 & Floor Beam Repair Modifikasi 1 & $1,49 \times 10^{6}$ & 322,893 \\
\hline Model 4 & Floor Beam Repair Modifikasi 2 & $1,72 \times 10^{6}$ & 279,581 \\
\hline
\end{tabular}

Dari hasil analisis keempat model, nilai tegangan Von Mises maksimum pada model 3 dan 4 bila dibandingkan kekuatan strukturnya dengan model 1 lebih rendah ( $M S$-nya lebih rendah dari model 1), hal ini karena fastener modifikasi dibuat lebih sedikit dibanding model 2 (sesuai SRM), namun secara kekuatan masih aman, sehingga struktur modifikasi aman digunakan untuk proses repair.

Hasil analisis model 2 sampai 4, nilai tegangan Von Mises maksimum pada pembebanan bending semakin membesar dengan pengurangan pemakaian jumlah fastener pada modifikasi area strap repair. Hal ini karena semakin sedikit fastener yang menahan beban, beban yang diteruskan ke fastener menjadi lebih besar sehingga tegangan kritisnya menjadi meningkat.

Dari perhitungan nilai $M S$ pada struktur repair dan modifikasi, semua part memiliki MS lebih besar dari nol sehingga ketiga struktur tersebut aman terhadap beban bending compartment main cabin.

\section{Kesimpulan}

Dari hasil analisis yang dilakukan pada penelitian ini, diperoleh kesimpulan sebagai berikut :

1. Pada pembebanan compartment main cabin model struktur yang mengalami retak, tegangan maksimum terjadi pada fastener sebesar $2,4 \times 10^{6} \mathrm{~N} / \mathrm{m}^{2}$. Kekuatan struktur retak lebih rendah dibandingkan dengan struktur repair sesuai $S R M$.

2. Pengurangan jumlah fastener pada struktur modifikasi strap repair menyebabkan naiknya tegangan kritis yang terjadi, hal ini karena fastener yang lebih sedikit menerima beban yang lebih besar. Dari perhitungan $M S$ ketiga struktur repair dan modifikasi longitudinal floor beam pesawat B737-300 aman terhadap pembebanan yang terjadi. 


\section{Daftar Pustaka}

Bruhn, E, F.,1965, Analysis and design of Flight Vehicles Sructures, Tri State Offset Company, USA.

Boeing 737-300, Structure Repair Manual, Chapter 51-00-00, 51-20-01, 51-20-06, 51-30-01, 53-60-5.

D. Cook, Robert, 1981, Concept and Applications of Finite Element Analysis, John Wiley \& Sons

Iryani, Leni, 2009, Analysis Of Riveted Joint Using Vlieger/Broek Equation, Jurnal Tekno Insentif 09, Volume 3 Nomor 1, Juli 2009.

Niu CY, Michael, 1988, Airframe Structural Design, Hong Kong Conmilit Press Limited.

Niu CY, Michael, 1997, Airframe Stress Analysis and Sizing, Hong Kong Conmilit Press Limited.

Peery, DJ, 1976, Aircraft Structure, Pensylvania State University, New York.

Popov, EP., 1978, Mechanics of Material, Prentice Hall Inc, New Jersey.

Suyogkumar W Balbudhe, 2013, Stress Analysis of Various Types of Riveted Lap Joint, International Jurnal of Engineering and Robotic Research (IJERT), Volume 2 No. 4, Oktober 2013. 
Djarot Wahju Santoso 